\title{
Exploring Design Principles of Bioclimatic Architecture and Double Skin Facades as A Convincing Tool for Energy Saving \\ * Dr. SERTAC ILTER
}

Faculty of Architecture, Eastern Mediterranean University, Famagusta, North Cyprus E mail: sertac.ilter@emu.edu.tr

\begin{tabular}{|l|}
\hline A R T I C L E I N F O: \\
\hline Article history: \\
Received 15 July 2018 \\
Accepted 23 September 2018 \\
Available online 13 October \\
2018 \\
\hline \\
Keywords: \\
Bioclimatic \\
Architecture, \\
Double-Skin Facades, \\
Thermal Comfort, \\
Heating, \\
Natural Ventilation, \\
Day Lighting. \\
\end{tabular}

This work is licensed under a Creative Commons Attribution - NonCommercial - NoDerivs 4.0. "CC-BY-NC-ND"

\begin{abstract}
A B S T R A C T
Different climates of different regions do not provide the required appropriate climatic conditions to ensure thermal comfort all year long. The goal to be pursued is to achieve the best interaction between climate, building and user behaviour. Bioclimatic buildings exploit climate in order to offer their occupants the most appropriate comfortable conditions. Especially, variations in hours of sunshine, in temperature, and rainfall of a particular climate signify establishing various strategies according to seasonal differences of particular region. In winter time assembling most of solar gain, and protecting the users from the cold (heating) are important. In summer; occupants/users need more protection from the sun (cooling). Thus, bioclimatic buildings reside in tune with these natural rhythms through consulting the most of natural lighting. This paper is aimed to enable architects to rediscover the principles of bioclimatic architecture and the modern technical and architectural means to achieve them. The study persuades adjusting the Double Skin Façades (DSF) design as the disciplined approach of ensuring the major strategies of Bioclimatic Architecture. Apparently, the study seeks three delineated bioclimatic approach daylight, thermal comfort and natural ventilation in DSF systems. The study views the DFS systems as the potential inclination for bioclimatic architecture ecological principles. On this basis, a connection between Bioclimatic Architecture and DFS systems are asserted and moderated within a generalized task.
\end{abstract}

JOURNAL OF CONTEMPORARY URBAN AFFAIRS (2018), 2(3), 60-66.

https://doi.org/10.25034/ijcua.2018.4719

www.ijcua.com

Copyright (C) 2018 Contemporary Urban Affairs. All rights reserved.

\section{Introduction}

Decades, the energy consumption came to the agenda as an alerting paradigm of major global concern. In view this fact; the many researches have accomplished a novel interest in the field of ecological studies in order to provide enhancing approaches and strategies. The building construction sector has been notified as the major fact on energy consuming. Their operational energy is commonly supplied in the form of electricity, which is engendered from fossil fuels. Overall, studies reported that buildings' energy use constitutes about one third of the global final energy use (G. B. Hanna, 2013). On this basis;

\footnotetext{
*Corresponding Author:

Faculty of Architecture, Department of Architecture, Eastern Mediterranean University, Famagusta, Northern Cyprus E-mail address: $\underline{\text { sertac.ilter@emu.edu.tr }}$
} 
sustainability spirit in architecture engaged with the manifestation of "more efficient energy use", where an allied relationship through the external and internal environment is adjusted to be asserted. This realm significantly influenced and correlated awareness on the selection of construction type and material use in architectural design, especially façade enterprises. In the explicit of sustainability beyond architecture has imposed various approaches in various scales of illuminating the ecological responsive allocation.

Fascinatingly to address the main paradigm of efficient energy use in design; the bioclimatic architecture appears as the grounded approach that signifies the major spirits (natural ventilation, heating, cooling and lighting) of efficient energy use in building design. Following "efficient energy use" aim of the sustainability in architectural design; the bioclimatic architecture demonstrates a responsive endorsement on indicating efficient way of energy use as a cognitive tool for design. In view of this fact; its principles particularly reside along with a natural dynamic interaction between user, their built environment and the outdoor climatic conditions. However, the determination of bioclimatic architecture can be adjusted either in vernacular buildings, or contemporary buildings without any style or era distinction. In other words; any type of building belonging any time dilemma might be classified as bioclimatic. In order to call a building as bioclimatic architecture; the ecological dimension of the building significantly must met with energy efficiency perspective as naturally achieving the way ventilation, heating, cooling and lighting Olgyay V. (1953), Aronin JE. (1953), Arens E et al. (1981), Lima A. (1995), Singh MK, Mahapatra S, Atreya S. (2010).

In recent; a significant interests has growth in Double Skin Façade (DSF) design and its usage due to its pragmatic benefits on energy conservation contributing to the energy efficiency goal of sustainability ( $N$. Safer, $M$. Woloszyn, J. J. Roux, and F. Kuznik, 2005). In recent demarcation DSF is resided in the definition of multi layer skin construction of contemporary architecture where an external skin adjoined to an internal skin through an intermediate space of airflow (J. Zhou and $Y$. Chen, 2010). In significant; the efficient energy use ideology is resembled in DSF with evacuating the solar radiation absorb upon a glazing envelope, which enhances continuous ventilation within the building. As a consequence; DSF impulses a minimized energy consumption use amongst accomplished cooling and heating (Z. YIImaz and F. Çetintas, 2005). However, its implementation is accompanied by significant challenges due to the complexity of the thermal and airflow phenomena that is involved in its behavior where adaptability is magnified in different climatic conditions (M. A. Shameri, M. A. Alghoul, K. Sopian, M. F. M. Zain, and O. Elayeb, 2011 ).

This paper investigates pragmatic deliberations of DSF for bioclimatic architecture as one of the most appropriate resided approaches of contemporary design. Thus, the study aims to fragment the DSF key parameters as a matching convincing tool for the design principles of bioclimatic architecture. The key parameters of DSF are demarcated within the framework of the study as daylight, thermal comfort and natural ventilation. The rationalized similarities between DSF and Bioclimatic Architecture are aimed to be met within a collective perspective. The questioned key primitives of energy efficiency in two correlated approaches are drawn to illuminate a utilized scheme as a convincing tool for design of contemporary era and sustainability.

\section{Incorporating Bioclimatic Architecture and DSF Principles.}

\subsection{Bioclimatic Architecture}

Bioclimatic Architecture imposes evolving climate responsive implantation in architecture through the use of appropriate project strategies considering the climatic differences of each place, in order to better improvement of the thermal comfort conditions for the occupants (Lamberts, 2006). Based on the global demarcation of international policyKyoto Protocol on sustainability; the bioclimatic architecture is identified as the income for reduction of energy use and other environmental impacts in order to obtain sustainability as an outcome within the challenging decade of climate change (Hyde and Rostvik, 2008). In deed; the approach provides an advantage on climate to control the heat transfer process through the right application of design elements and building technology (Goulart and Pitta, 1994; ERG, 1999 op cit). The energy save has mainly promoted with the ensured comfort conditions for occupants/users into building. Extensively in spirit; passive low energy techniques are persuaded for generating environmentally interactive, efficient and contented to human comfort standards (Yeang, 1996). On this basis the bioclimatic architecture principles are 
developed on representing energy efficient strategies, while the applicability is modified based on the environmental characteristics of the region and building type (Maciel, 2007).

Various researches are intended to prospect the principles of bioclimatic architecture (Machaira et al, 2012). With all of these perspectives, EDP, Axarli \& Teli and Lambertin have made the most comprehensive approach to bioclimatic architecture approach.

Listed below are different set of principles as outlined by previous researchers such as Lamberts (2006) and Axarli \& Teli (2008) EDP Energy (2011) (Table 1). According to the set of principles, similarities and dissimilarities can be observed. According to comparing the various principles thermal comfort and natural lighting are the most dominant feature for bioclimatic architecture.

Table 1. Different set of principles as outlined, Lamberts (2006) and Axarli \& Teli (2008) EDP Energy (2011)

\begin{tabular}{|c|c|}
\hline According to Lamberts & $\begin{array}{l}\text { 1. Building thermal performance. } \\
\text { 2. Day lighting. } \\
\text { 3. Heating and pas sive solar cooling. } \\
\text { 4. Natural ventilation. } \\
\text { 5. Thermal comfort. } \\
\text { 6. Adequate shading. }\end{array}$ \\
\hline According to Axarti \& Teli & $\begin{array}{l}\text { 1. Achievement of thermal comfort. } \\
\text { 2. Improvement of visual comfort. } \\
\text { 3. Creation of acoustic comfort. } \\
\text { 4. Improvement of air quality. } \\
\text { 5. Improvement of building's energ } \\
\text { behavior. }\end{array}$ \\
\hline According to EDP Energy & $\begin{array}{l}\text { 1. Microclimate improvement. } \\
\text { 2. Systems and passive cooling techniques. } \\
\text { 3. Exploitation of soler energy. } \\
\text { 4. Thermal protection of buildings and } \\
\text { 5. Natectionthrough shading. } \\
\text { 6. Acoustic protection. }\end{array}$ \\
\hline
\end{tabular}

\subsection{Double Skin Façade (DSF)}

DSF can be defined as a traditional single façade doubled inside or outside amongst a secondary airflow break- glazed façade. In other words; The DSF is a system consisting of two glass skins placed in such a way that air flows within an intermediate cavity. The attribution of imposing a skin ideology is illuminative and spirited with the accomplished airflow cavity. A ventilated cavity - having a width, which can range from several centimeters to several meters - is positioned between these two skins. Though the heat extraction, the solar shading devices are placed inside the cavity (Poirazis 2004). Besides the automated equipment-shading devices; motorized openings or fans, are also frequently preferred to be integrated into the façade. The main difference between a ventilated double façade and an airtight multiple glazing lies in the intentional and probably controlled ventilation of the cavity of the double façade, with or without integrating a shading device in the cavity separating the glazing (BBRI, 2004). In significant, pair of glass called- skins is separated upon a validated air space/ corridor. The main layer of glass imposes the insulation, while the air space/corridor between the layers of glass implements insulation against temperature extremes, winds, and sound. Sunshading devices are often located between the two skins. All elements can be arranged differently into numbers of permutations and combinations of both solid and diaphanous membranes (Harrison, Meyer-Boake, 2003). Extensively, ventilation of the cavity can be natural, fan supported or mechanical. Apart from the type of the ventilation inside the cavity, the origin and destination of the air can differ depending mostly on climatic conditions, use, location, occupational hours of the building and the HVAC strategy.

\subsubsection{The Components of DSF and Passive Design}

The DSF incorporates the passive design strategies of natural ventilation and solar heat gain into the fabric of the contemporary building. These are the key components of the DSF regarding to energy efficiency and human comfort that certain types of double skin façades are controlled. These key primitives are daylight, thermal comfort and natural ventilation (Boake, T. M., Bes, B., \& Arch, M., 2003).

Solar Heat Gain

In DSFs; the control of solar heat gain is obtained through the use of shading devices (typically horizontal blinds) contained within the air cavity, where the cavity also demonstrates the ability to absorb some of the incoming solar radiation. In significant; the external shading devices claim efficiently reducing the solar heat in highly glazed buildings. Moreover; horizontal blinds allow getting the specific advantages for daylighting.

There are various configurations of horizontal blind shading devices. They can either be fixed elements or, typically, operable units that are either controlled through the occupant or sensors within the building. However; in each type the air cavity space has the ability to draw off some of the initial solar radiation. Convection currents carry the heated air upwards and extracts to the exterior through the venting arrangement at the top of the cavity. 
"A double-skin façade reduces heat losses because the reduced speed of the air flow and the increased temperature of the air in the cavity lowers the rate of heat transfer on the surface of the glass. This has the effect of maintaining higher surface temperatures on the inside of the glass, which in turn means that the space close to the window can be better utilized as a result of increased thermal comfort conditions" (Compagno, 1995)

Consequently; the buffer zone allows for increased use of the perimeter zone of the space that typically requires heating or cooling mechanisms against the exposed glazing. Also, with the use of improved solar heat transmission values for glazing the absorption and reflection of heat can be controlled to minimize solar heat gain. This can be accomplished through the use of what is referred to as 'spectrally selective glazing';

Spectral Selectivity refers to the ability of a glazing material to respond differently to different wavelengths of solar energy - in other words, to admit visible light while rejecting unwanted invisible infrared heat. Newer products on the market have achieved this characteristic, permitting much clearer glass than previously available for solar control glazing. A glazing with a relatively high visible transmittance and a low solar heat gain coefficient indicates that a glazing is selective. spectrally selective glazing use special absorbing tints or coatings, and are typically either neutral in color or have a blue or blue/green appearance. An ideal spectrally selective glazing admits only the part of the sun's energy that is useful for daylighting (O'Connor, Jennifer with: Lee, E., Rubinstein,F., Selkowitz,S., 1997).

Natural Ventilation

Natural ventilation allows cooling and ventilating the space through the use of passive ventilating methods. The passive use of air currents plays a significant contribution on reducing the energy consumption of the building. Within this process; the exterior glazing of the double skin demonstrates a layer of air subsequent to the exterior wall of the building that is not affected by high velocity wind. This buffer zone as a key component to the double skin façade is typically the area admission by the occupants/users for natural ventilation. In some instances; the use of operable windows in the exterior glazing skin is also used for natural ventilation.

"The reduction of wind pressure by the addition of the extra pane of glass means that the windows can be opened even in the uppermost floors of a high-rise building. Natural ventilation of offices by fresh air is much more acceptable to the building's users and it has the additional benefits of reducing investment in air handling systems and also reducing energy consumption." (Compagno, 1995, p. 94)

On this basis; a typical strategy of the double skin façade is to compartmentalize the buffer zone into separate regions with air supplied by grilles or vents at each level or individual zone. This compartmentalization disregards the impact of noise, sound, smoke and heat transfer from one section, level or room to the next area. The use of vents or grilles allows the control of incoming air by reducing air velocity, protecting from rain and reducing noise transmission from the exterior. Such control allows occupant access to the natural ventilation in constructions. "Most effective ways to reduce building services energy consumption is to exploit natural means and depend less on mechanical techniques" (Farmer, Graham and Guy, Simon, 2003). Extensively; the air cavity space and integrated solar shading devices control the solar heat gains that would typically require the use of mechanical means of air conditioning and air extraction.

\section{Daylighting}

Daylighting is important in two ways; first it reduces the amount of artificial lighting required, and secondly the quality of light from daylight is preferential to artificial lighting. The double skin façade with its increased glazing coverage improves the access to daylighting in the space. The increased daylighting component of the completely glazed façade initiates excessive glare and heat at certain times of the day. These increases require advance actions in design to struggle their negative effects. Solar shading devices are designed into the air cavity space to decrease solar heat gain through the glazing and reduce the amount of glare to bring forth by the increased access to daylight.

\section{Findings}

The indoor environment is always under the intense of to be controlled for providing the users needs by the delivery of different building services such as heating, cooling, ventilation, and lighting. This can be explained from the traditional idea that meeting occupant needs on comfort and energy savings could be met by the formation of a static, ultimate thermal environment. Resembling the ultimate thermal 
environment adjustment as the major gizmo; the connections on daylight, thermal comfort and natural ventilation strategies of Bioclimatic Architecture and DSF Design are utilized in below Table 2.

Table 2. Daylight, Thermal Comfort and Natural Ventilation Strategies of Bioclimatic Architecture and DSF Systems.

\begin{tabular}{|c|c|c|c|}
\hline & & Bioclimatic Architecture & DSF systems \\
\hline \multirow{6}{*}{ 总 } & Shadivg & $\begin{array}{l}\text { : Canopies } \\
\text { - Onerhangr } \\
\text { - Reflectors }\end{array}$ & $\begin{array}{l}\text { - Fived Monaloke Shading } \\
\text { Ihevices contained in air } \\
\text { cavity. } \\
\text { - Reflectors }\end{array}$ \\
\hline & Copostering & : Glass mindow surfaces & - Trangparem Surfaces \\
\hline & Pencedation & : Windons & $\begin{array}{l}\text { - Gluzed exterior and interior } \\
\text { stin layers }\end{array}$ \\
\hline & Diserifutbon & - Windoms & - Windomax \\
\hline & & $\begin{array}{l}\text { - Reflectors } \\
\text { - Imerior surfaces }\end{array}$ & $\begin{array}{l}\text { : Reflectows } \\
\text { I Imeriar suffaces }\end{array}$ \\
\hline & Cousbolliting & - Adjestuble blinds & - Adjestuble venetian blinds \\
\hline \multirow{4}{*}{ 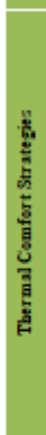 } & Heat Captewivg & 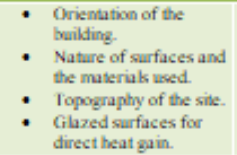 & $\begin{array}{l}\text { - Oriemation of the DSF. } \\
\text { Gluzed surfaces for direct } \\
\text { heat gin. } \\
\text { - Truansmiting diffined solar } \\
\text { radiation by glazed layers }\end{array}$ \\
\hline & Sovage & 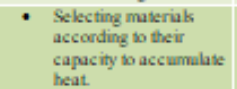 & - Abeorptive double glaring \\
\hline & Reteration & 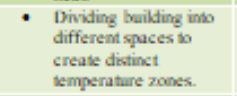 & $\begin{array}{l}\text { - Compartmenting the buffer } \\
\text { zome (air caving) into } \\
\text { separated regions with air } \\
\text { sapplied by grilks of vems. }\end{array}$ \\
\hline & Distifhus ing & $\begin{array}{l}\text { - Thermo circulution of } \\
\text { the air. } \\
\text { - Powered ventilation } \\
\text { system. }\end{array}$ & $\begin{array}{l}\text { - Thermo circulat tion of the } \\
\text { air thronght air cavity. }\end{array}$ \\
\hline \multirow{4}{*}{ 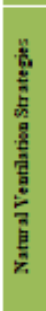 } & Shanding & - Permunemimobile & - Shading devices combined \\
\hline & & : Sifficiem insulation & \\
\hline & $\begin{array}{l}\text { Discipativg excess } \\
\text { heat }\end{array}$ & $\begin{array}{l}\text { - Oulles (chimney } \\
\text { effect) }\end{array}$ & $\begin{array}{l}\text { - Air cavity } \\
\text { Outlest/ inles (stack effect } \\
\text { and chimney effect) }\end{array}$ \\
\hline & $\begin{array}{l}\text { Conlivivg } \\
\text { stowatione }\end{array}$ & 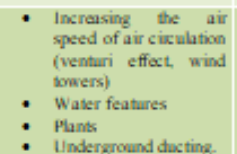 & $\begin{array}{l}\text { - Increasing the air spoed of } \\
\text { air cicultion (venturi } \\
\text { effect, wind bowerss) } \\
\text { : Air vents } \\
\text { Mamally opernble } \\
\text { windows on interios }\end{array}$ \\
\hline
\end{tabular}

Throughout reading the indicated findings from the listed Table 2; the following issues are more extensively and preciously conducted in explanation.

The daylight strategy intents to improve how natural light is captured and allowed to penetrate a space, and to improve how it is then diffused and focused. Controlling light to avoid visual discomfort must also be considered. The intelligent use of daylight allows the reduction of electricity consumption for lighting.

- $\quad$ Shading and Control: Excessive daylight penetration can cause visual discomfort. This can be controlled by architectural features like canopies, overhangs and reflectors in Bioclimatic Architecture, and with fixed or movable shading devices which contained in air cavity or exterior layer of DSF systems.

- Capturing: Windows into spaces convey a certain amount of daylight. This can be available in Bioclimatic Architecture with designing required size of windows and reflective surfaces on the ground such as, water elements or paving and also fully glazed transparent surfaces may contribute to capturing more light in DSF systems.

- Penetration: The way daylight penetrates into spaces depending on the position, orientation, angle, size and type of glazing which are necessary circumstances for Bioclimatic Architecture, but DSF systems can occur penetration of daylight by fully glazed exterior of interior layer.

- $\quad$ Distribution: Daylight can be diffused by an appropriate type of glazing usage or by reflectors that allow light for penetration, both in Bioclimatic Architecture and DSF systems.

The thermal comfort strategy is a response predominantly to winter comfort: capturing the heat from solar radiation, storing it in the mass of the structure.

- Heat capturing: Capturing heat in Bioclimatic Architecture comprises of storing solar energy and converting into heat. The solar radiation received by a structure depends on climate together with the orientation of the building, the nature of its surfaces and the materials used, on the topography of the site and glazed surfaces. In DSF systems, orientation of DSF, directs heat gain and transmits diffused solar radiation through glazed layers that can capture heat.

- Storage: Heat storage can be accomplished with materials among accumulating heat capacity and absorptive double-glazing for DSF systems.

- Retention: Retention is the air-tightness of the building's skin together with the insulation properties of its walls that reduce heat loss in Bioclimatic Architecture; dividing a structure into different spaces for creating a distinct temperature zones. Same idea can be used in DSF systems by compartmenting the air cavity into separated regions with air supplied by grills or vents.

- Distribution: Distribution means conveying the air to the spaces. Air (heat) can be distributed with the thermo-circulation of the air (rising movement of warm air). This can be achieved through the air cavity that DSF systems contain where raised air must also be regulated according to the spatial needs and usage that Bioclimatic Architecture claims.

The natural ventilation strategy is a response to the requirements for summer comfort: shading from solar radiation, dissipating excess heat and cooling down naturally.

- Shading: Bioclimatic Architecture essentially sets the external shading screens, 
which could be permanent or mobile. In DSF systems; shading devices generally arise in the air cavity for creating fully glazed façade without any additional architectural features. In addition to this; sufficient insulation should be used to prevent accumulation of heat.

- $\quad$ Dissipating Excess Heat: Dissipating of excess heat can be achieved through natural ventilation by using outlets, where temperature differences create a chimney effect in Bioclimatic Architecture. Likewise; DSF systems can achieve dissipating of excess heat for creating stack and chimney effect through the air cavity by using air inlets and outlets.

- Cooling the Structure: Cooling in Bioclimatic Architecture and DSF systems can be easily achieved by natural means. Common solution to ensure ventilation is to increase the speed of air circulation by venturi effect or wind towers created with buffer zone (air cavity). DSF systems also comprise operable windows, which located in the internal layer of the skin and air inlets, both on external and internal layers. In addition to these; some natural features can be used for cooling such as water features, plants and underground ducting, etc. in Bioclimatic Architecture.

\section{Conclusion}

Bioclimatic Architecture promotes valid major strategies to be considered as a major framework leading the ecological approaches in building industry. The general framework of Bioclimatic Architecture significantly estimates the grounds on understanding sustainability and its ecological implementations in building industry. Bioclimatic Architecture principles and strategies emphasize the pragmatic need for an amalgamated and universal approach on implementing sustainability in building projects. The challenge for the designers is to bring different bioclimatic architecture principles together with contemporary ways. The main challenge with highly glazed buildings lies especially in their ability to respond and acclimatize rapidly to the external environment according to occupants' requirements throughout the year. This is feasible by means of high-tech systems to control temperature, light and ventilation. According to the findings, an excessive correspondence has been comprehended between DSF systems and Bioclimatic Architecture strategies. Reducing heat demand, providing view through highly glazed surface, controlling solar heat gain, allowing natural ventilation with provided thermal insulation barrier, reducing artificial lighting to improve occupants comfort are all appropriate to be achieved in DSF systems. Consequently; DSF systems of contemporary architecture can be illuminated as the equivalent trend of Bioclimatic Architecture that adjusts its fundamental ecological strategies on daylight, thermal comfort and natural ventilation.

\section{Acknowledgement}

This research did not receive any specific grant from funding agencies in the public, commercial, or not-for-profit sectors.

\section{References}

Arens E., et al. (1981). A new bioclimatic chart for environmental design. In: de Oliviera Fernandes, Woods JE \& Faist AP (eds) Building energy management. Permagon Press, Oxford. https://iglobal.jst.go.jp/en/detail? JGLOBAL ID= 200902057484001433\&rel=0

Aronin JE. (1953). Climate and architecture, a Progressive Architecture book. Reinhold, New York.

https://www.rarebookstore.net/pages/books/7 63/architecture-jeffrey-ellis-aronin/climatearchitecture-progressive-architecture-book

Axarli, K. and Teli, D., (2008). Implementation of bioclimatic principles in the design of urban open spaces: microclimatic improvement for the cooling period of an open space adjacent to the sea. Paper presented on the PLEA 2008 25th Conference on Passive and Low Energy Architecture, Dublin, 22nd to 24th October 2008.

https://www.researchgate.net/publication/317 305540_Implementation_of_bioclimatic_principl es in the design of urban open spaces micr oclimatic improvement for the cooling_perio d_of_an_open_space adjacent_to the sea

BBRI (2004). 'Ventilated double façades Classification and illustration of façade concepts', Belgian Building Research Institute BBRI Department of Building Physics, Indoor Climate and Building Services. http://www.bestfacade.com/pdf/downloads/ Bestfacade WPl Report.pdf

Boake, T. M., Bes, B., \& Arch, M. (2003). Understanding the General Principles of the Double Skin Façade System. https://www.semanticscholar.org/paper/Under standing-the-General-Principles-of-the-DoubleBoake-

Chatham/2cc9d32d259f736d8da64fda37e5f73 8c9bf16af

Compagno, Andrea (1995). Intelligent Glass Facades; Material, Practice, Design, Birkhauser, Basel,
Switzerland. 
https://www.amazon.co.uk/Intelligent-GlassFacades-Material-Practice/dp/376435996X

Energy Design Partnership, EDP Energy (2011). Principles of bioclimatic architecture. Retrieved on March 9, 2012 from www.edpenergy.com

Farmer, Graham and Guy, Simon (2003). Visions of Ventilation: Pathways to Sustainable Architecture, Department of Architecture, University of Newcastle upon Tyne, Newcastle upon Tyne, UK. https://www.researchgate.net/profile/Graham Farmer/publication/254955507_Visions_of_Ven tilation_Pathways to Sustainable_Architecture/ links/55e59e5308aebdc0f58a5563.pdf

G. B. Hanna (2013). Green energy and green buildings in Egypt, Int. J. Eng. Res. Appl., 3(4), 466-470.

http://citeseerx.ist.psu.edu/viewdoc/download ? doi=10.1.1.414.7838\&rep=rep \& \&type=pdf

Goulart, S. and Pitta, T. (1994). Advanced topics in bioclimatology to building design, regarding environmental comfort. Florianopolis: PPGECUFSC

PPGEC-UFSC.

http://kubanni.abu.edu.ng/ispui/bitstream/123 456789/6368/1/APPLICATION\%200F\%20BIOCLIM ATIC\%20ARCHITECTURE\%2OPRINCIPLES\%20IN\%20 THE\%20DESIGN\%200F\%20HOTEL\%20AT\%20KATSI NA\%20NIGERIA.pdf

Harrison K., Meyer-Boake T. (2003). The Tectonics of the Environmental Skin, University of Waterloo, School of Architecture. https://www.tboake.com/ds/double.pdf

Hyde, R., (2008). Bioclimatic Housing Innovative Designs for Warm Climates. London, UK: Earthscan.

https://www.amazon.com/Bioclimatic-HousingInnovative-Designs-Climates/dp/1844072843

J. Zhou and Y. Chen (2010). A review on applying ventilated double-skin facade to buildings in hot-summer and cold-winter zone in China, Renew. Sustain. Energy Rev., 14(4), 1321-1328.

Lamberts, R., (2006). Bioclimatic Buildings: A paper presented to the Federal University of Santa Catarina.

https://doi.org/10.1016/i.rser.2009.11.017

Lima A. (1995). The development of bioclimatic design. PhD Thesis, The University of Queensland, Brisbane. https://books.google.com.tr/books/about/The Development_of_Bioclimatic_Design.htmle id=6 bXPSAAACAAJ\&redir esc $=y$

M. A. Shameri, M. A. Alghoul, K. Sopian, M. F. M. Zain, and O. Elayeb (2011). "Perspectives of double skin façade systems in buildings and energy saving," Renew. Sustain. Energy Rev., 15(3), $1468-1475$.

https://doi.org/10.1016/j.rser.2010.10.016
Machaira, et.el. (2012). Green Hotelling: A Feasibility Study in the Hellenic Island of Skyros. Paper presented at FIG Working Week 2012. Rome,

Italy. https://www.fig.net/resources/proceedings/fig proceedings/fig2012/papers/ts03c/TSO3C mac haira_labropoulos_et_al_6056.pdf

Maciel, A. A. (2007). Bioclimatic Integration into the Architectural Design. Published PhD. Thesis. University of Nottingham, United Kingdom. http://www.labeee.ufsc.br/sites/default/files/p ublicacoes/teses/TESE_Alexandra_Albuquerqu e_Maciel.pdf

N. Safer, M. Woloszyn, J. J. Roux, and F. Kuznik (2005). Modeling of the double-skin facades for building energy simulations: Radiative and convective heat transfer," Building Simulation, 1067-1074.

http://www.inive.org/members area/medias/p df/inive/ibpsa/bs05_1067_1074.pdf

O'Connor, Jennifer with: Lee, E., Rubinstein,F., Selkowitz,S. (1997). Tips for Daylighting with Windows; the Integrated Approach, Ernest Orlando Lawrence Berkeley National Laboratory.

https://facades.lbl.gov/sites/all/files/tips-fordaylighting-1997.pdf

Olgyay V. (1953). Bioclimatic approach to architecture, in BRAB conference report No.5 National Research Council, Washington, DC. p. 13.

https://scholar.google.com/scholar_lookup?titl e=Bioclimatic\%20approach\%20to\%20architect ure \&author $=\mathrm{V} . \% 20$ Olgyay \&pages $=13-$

23\&publication_year $=1953$

Poirazis, H. (2004). Double Skin Façades for Office Buildings - Literature Review, Division of Energy and Building Design, Department of Construction and Architecture, Lund Institute of Technology, Lund University, Report EBD-R04/3,

2004.

http://www.ebd.Ith.se/fileadmin/energi_byggn adsdesign/images/Publikationer/Bok-EBD-R3G5 alt 2 Harris.pdf

Singh MK, Mahapatra S, Atreya S. (2010). Thermal performance study and evaluation of comfort temperatures in vernacular buildings of Northeast India. Build Environment; 45(2): 320-329. https://doi.org/10.1016/i.buildenv.2009.06.009

Yeang, K., (1996). The Skyscraper Bioclimatically Considered, London Academy. https://doi.org/10.1017/s1359135500001470

Z. YIlmaz and F. Çetintas, (2005). Double skin façade's effects on heat losses of office buildings in Istanbul, Energy Buildings, 37 (7), 691-697.

https://doi.org/10.1016/j.enbuild.2004.07.010 